\title{
The Impact of Capital Structure on Corporate Performance in Nigeria: A Quantitative Study of Consumer Goods Sector
}

\author{
Sebastain Ofumba Uremadu* and Onuegbu Onyekachi \\ Department of Banking and Finance, MOUAU, Nigeria \\ Received: 眥 November 19, 2018; Published: 些 November 30, 2018 \\ *Corresponding author: Sebastain Ofumba Uremadu, Department of Banking and Finance, MOUAU, Nigeria
}

\begin{abstract}
This study examined the impact of capital structure on corporate performance in Nigeria with special focus on consumer goods firm sector of the economy. Multiple regression of ordinary least square (OLS) analytical technique was used to analyse the data. The results from the study showed a negative and insignificant impact of capital structure on corporate performance of the consumer goods firm sector of Nigeria. That long-term debt ratio to total asset had a negative and insignificant impact on returns on assets, while total debt ratio to equity also had a negative and insignificant impact on returns on assets. The study, therefore, concluded that capital structure is not a major determinant of firm performance. Hence, the study recommends that managers should be careful while using debt as a source of finance since a negative impact exist between the capital structure and corporate firm's performance. Also, that corporate firms should try to finance their activities with retained earnings and use debt as a last option as this is consistent with the pecking order theory. This implies that, the study strongly recommends that corporate firms should use more of equity than debt in financing their business activities, this is because in spite of the fact that the value of a business can be enhanced with debt capital, it gets to a point that it becomes detrimental (negative) or unfavourable to the business.
\end{abstract}

Keywords: Capital Structure; Corporate performance; Consumer goods sector; Nigeria

\section{Introduction}

Capital structure is one of the hotly debated finance topics or theories among the studies of researchers and scholars. Its importance derives from the fact that capital structure is closely related to the ability of firms to fulfil the needs of various stakeholders. Capital structure represents the major claims to firm's assets. This includes the different types of both equities and liabilities. Capital structure of a firm is such a vital factor that it enhances its performance Uremadu and Efobi [1]. A firm's capital structure refers to the mix of its financial liabilities. It has been an important issue from the strategic management standpoint since it is linked with a firm's ability to meet the demands of various stakeholders as stated elsewhere already in this work. Capital structure is the most significant discipline of company's operations. Capital structure decision is a vital decision with great implication for the firm's sustainability. The ability of the organization to carry out their stake holders need is closely related to the capital structure. The determination of a company's capital structure is a difficult task to achieve. According to Uremadu [2], capital structure of a firm includes retained earnings, debt and equity capitals. This is in agreement with, Pandey (2010), which stated that the term capital structure is used to represent the proportionate relationship between debt and equity. Equity includes paid-up share capital, share premium and reserves and surplus (i.e. retained earnings).

Capital structure has been a major issue in financial economics ever since Modigliani and Miller showed in 1958 that given frictionless markets, homogeneous expectations; capital structure decision of the firm is irrelevant. By relaxing the assumptions and analyzing their effects, theories seek to determine whether an optimal capital structure exists or not, and if so, what could possibly be its determinants. The relationship between capital structure decisions and firm value has been extensively investigated in the past few decades. Capital structure could have two effects; according to Desai [3], firms of the same risk class could possibly have higher cost of capital with higher leverage. Also, that capital structure may affect the valuation of the firm, with more leveraged firms, being riskier and consequently valued lower than the less leveraged firms. If the manager of a firm has the shareholders' wealth maximization as his objective, then capital structure is an 
important decision, for it could lead to an optimal financing mix which maximizes the market price per share of the firm.

Every business whether newly born or an ongoing, requires fund to carry out its activities as no success is achievable in the absence of fund. The needed fund may be for daily running of a firm or for business expansion. This tells how important fund is in the life of every business. This fund is referred to as capital. Capital therefore refers to the means of funding a business. Firms that are willing to raise capital for their activities normally source their funds through two major sources. These sources are internal and external sources. The internal source refers to the funds generated from within an enterprise which is mostly retained earnings. It results from success enterprises earn from their activities. Firms may in the same vein look outside to source for their needed funds to enhance their activities. Any fund sourced not from within the earnings of their activities is termed external financing. The external funding may be by increasing the number of co-owners of a business or outright borrowing in form of loan. Financing and investment are two major decision areas in a firm. In the financing decision the manager is concerned with determining the best financing mix or capital structure for his firm. Capital structure decision is the mix of debt and equity that a company uses to finance its business (Damodaran, 2001). Capital structure theory is an essential reference theory in firm's performance. The capital structure refers to firms' mixture of debt and equity financing. To pursue a policy of an optimal capital structure, is one of the most important and complex issues to resolve in an organizational management. Most firms' capital especially during the beginning of their businesses comes from combinations of various debt and equity proportions. This is gotten from shareholders' funds to finance their company's needs and balance their leverage which signifies the good standing of the firm. Debts could be acquired in form of bonds, short- and long-term credit while equity could equally be acquired through participation of stakeholders or common stocks and retained earnings. Following the work of Modigliani and Miller [4], a substantial amount of effort has been put forward in corporate finance theory to determine the factors that influence a firm's choice of capital structure. The issue of finance has been identified as the major reason for firms failing to start or grow. It is pertinent for firms in Nigeria to make the best choice in financing their activities and grow over time.

After over half a century of studies on this important topic, economists and financial experts have not reached an agreement on how and to which extent corporate firms' capital structure impacts on their performance. However, this study would contribute to the empirical studies on how capital structure would impact on corporate firms' performance in the Nigerian context with special focus on consumer sector. By the time the study is completed the paper could be in a position to ascertain if it imparts positively or negatives on firm performance among corporate firms in Nigeria.

\section{Objectives of the Study}

The main objective of this study is to examine impact of capital structure on corporate performance among Nigerian firms under study. Specifically, this study is undertaken to:

a) Examine impact of long-term debts to total assets ratio of returns on assets in the Nigerian corporate environment.

b) Examine impact of total debts to equity ratio impact of returns on assets in the Nigerian investment climate.eview of Related Literature

\section{Concept of Capital Structure}

Capital structure is the way a company finances itself by combining long-term debt, short-term debt, and equity capital (Hsiao, 2009). It shows how a company finances its overall operations and growth by using different sources of funds. Capital structure of firms varies with its size, type and some other characteristics or determinants such as age of company, company size, asset structure, profitability, company growth, company risk and liquidity [5].

The purpose of managing capital structure is to mix the financial sources in order to maximize the wealth of shareholders and minimize the company's cost of capital [6]. Therefore, one of the financial manager's responsibilities is to manage and decide the optimal capital structure. This decision on capital could be critical because it may affect the company's overall performance and it involves a trade-off between risk and return. A rise in debt will increase the company's risk and the expected return and high risk means an increase in debt which could lead to a decrease in stock price and an increase in the expected return of stock prices (Brigham and Huston, 2001).

Capital structure concerns the composition of the liability of a company, which is the relative to the several financial sources in the composition of the total obligation (Weston and Brigham, 2000). Capital structure decision is very vital for any organization, every organization wants a mix of arrangements that eventually achieves or increases its performance and/or profitability and overall value. Different alternatives available to firms to finance itself sometimes are through issuing of shares, securities or some time from debt. Firms take the combinations, which increase their efficiency, performance and/or profitability and its value.

Capital structure decisions are very difficult in an uncertain economy such as in Nigerian investment climate with the existence of the macroeconomic environment factors such as high interest rates in double figures and volatility in the economy and the political situations are big factors or problems for the combination of capital structure. However, many theories and practical approaches exist on capital structure. 


\section{Optimal Capital Structure}

The optimal capital structure of a firm is the capital structure with minimum cost implications which maximized the total value of the firm. It could be obtained using a combination of debt and equity financing that would give the firm a minimum cost of capital and enhanced market value. The amount of debt contained in a firm's optimal capital structure is referred to as its debt capacity. The debt capacity has implications on the borrower. Borrowed funds usually carry fixed charge interest expense. The borrower is under obligation to pay interest to debt-instrument holders irrespective of whether profits or losses are made. If a borrower fails to pay the fixed interest charges in time, the creditors are at liberty to take legal action against the borrower to get the payments and in extreme circumstances, it may force the borrower into liquidation [7].

\section{Debt Financing}

Debt financing implies raising fund through selling of bonds, mortgages or borrowing directly from financial institutions. You must repay borrowed funds as at when due with interest charged. A lender incurs risk and charges a corresponding interest based on that risk. The lender usually assesses a variety of factors such as the strength of the business plan, management capabilities, financing and the past credit history of the borrower before lending it to him. Debt financing could be divided into two categories: the long-term debt financing and the short-term debt financing:

a) Long Term Debt Financing: Include items such as equipment, land, buildings and machineries. According to Ward (2008), with long term financing, the scheduled repayment of loan and estimated useful life of the assets extends over more than one year.

b) Short Term Debt Financing: It the fund for day-to-day activities or financing needs of firms. This include inventory, supplies of raw material and paying of employees' salaries or money owed to them. They are called short term debt fund because the fund that was borrowed will be expected to be paid back in less than one year.

Besides, Sources of Debt Financing also exist. And they include;

a) Overdraft: The overdraft is a type of short-term debt financing in which a business owner can open a current account with a bank, the bank established a credit limit and the business owner is allowed to withdraw up to that limit despite the fact that there are not enough funds in the account to cover the amount. In this case, the business owner will only pay interest for the time he uses the money.

b) Banks: the most used type of debt financing is the bank loan, which requires the business owner to make monthly payments on the principal amount plus interest. However, banks are reluctant to take risks and as such, this type of debt finance is usually beyond the reach of a start-up business. Another stumbling block for a start-up business from obtaining a loan is the bank's requirement for the provision of collateral. Commercial banks have more experience in providing business loans than ordinary savings or micro finance banks and that is why it is necessary to study the differences between bank and terms before deciding on which institution to approach for a loan;

c) Credit Unions: Credit unions provide business loans, but their services are usually exclusive to members of a labor union or the employees of a company. Credit unions have higher loan approval rates than banks, and their terms and interest rates are usually much more favourable.

\section{Equity Financing}

Equity financing is the method of raising capital by selling firm's stock to investors, in return for investment. The shareholders receive ownership interest in the firm. In order to grow, a firm will need additional capital, which may be obtained through debtor equity. Equity financing involves the sale of firm's stock and giving a portion of the ownership of the firm to the investors in exchange for cash. The proportion of the firm that will be sold in an equity financing depends on how much the owner has invested in the firm and the worth of the investment at time of the financing.

In addition, Sources of Equity Financing do exist which include the followings;

a) Personal Savings: Personal savings is the first place an entrepreneur should look for money which is the most common source of equity capital for starting a business. Outside investors and lenders expect the entrepreneur to put some of his or her own capital into the business before investing theirs

b) Friends and Family Members: After emptying his or her pocket, an entrepreneur should turn to those most likely to invest in the business, friends and family members. Ten (10) percent of business owners turn to family and friends for capital. Other sources of equity financing include: shareholders, and proceeds from Sales.

c) Theoretical Review of Literature: Several studies have been conducted to examine the theories of capital structure which include the following:

\section{Miller and Modigliani Theory}

One of these studies was carried out by Modigliani and Miller (1958), Modigliani and Miller (MM) Theory illustrates that under certain key assumptions, firm's value is unaffected by its capital 
structure. Capital market is assumed to be perfect in Modigliani and Miller's world, where insiders and outsiders have free access to information; no transaction cost, bankruptcy cost and no taxation exist; equity and debt choice become irrelevant and internal and external funds can be perfectly substituted. The M-M theory argued that the value of a firm should not depend on its capital structure. The theory argued further that a firm should have the same market value and the same weighted average cost of capital at all capital structure levels because the value of a company should depend on the return and risks of its operation and not on the way it finances those operations. If these key assumptions are relaxed, capital structure may become relevant to the firm's value. Meanwhile, this theory was criticized on the ground that perfect market does not exist in real world. Attempts to relax these assumptions particularly the idea of no bankruptcy cost and no taxation led to the trade-off theory.

\section{Trade-off Theory}

Myers (1984), proposed the Trade-off Theory that supports the relevance of capital structure. This theory suggests that firms have optimal capital structure and they move towards the target. It further emphasized that when debt is employed in capital structure, firms are faced with the challenges of tax benefit and bankruptcy cost, thus the need for trade-off between the two. Under trade-off theory, the firms with high growth opportunities should borrow less because it is more likely to lose value in financial distress. This is because trade-off theory predicts safe firms. That is firms with more tangible assets and more taxable income to shield should have high debt ratios. While a risky firm that is firms with more intangible assets that the value will disappear in case of liquidation, have to rely more on equity financing. In terms of profitability, trade-off theory predicts that more profitable firms should mean more debt serving capacity and more taxable income to shield; therefore, a higher debt ratio will be anticipated.

\section{Pecking Order Theory}

Pecking Order Theory is another theory which states that the purpose of a firm is to maximize the shareholder's wealth. This theory states that there is a hierarchy in choosing sources of financing (Smart, 2004). A firm will prefer to use internal financing than external financing. The internal financing is from the retained earnings that are earned by doing operational activities. The firm will choose securities with lower risks, if it needs external financing. This theory is of the opinion that the main problem in determining the capital structure of a firm is asymmetric information between managers and investors (Amidu, 2007). In fact, this theory argues that the manager of a firm will act on the existing stakeholder's interest (Abor, 2005). Consequently, the new investors will have a perception that the manager does not support their interests. Mackie-Mason (1990), opined that the importance of asymmetric information gives a reason for firms to care about those who provide the funds because different fund providers would have different access to information about the firm and different ability to monitor the company's behaviour. This is consistent with the pecking order theory since private debt will require better information about the firm than public debt. While, Sunder (1999), asserted that firms follow the pecking order theory in their financing decisions where firms with a positive financial deficit are more likely to issue debt.

\section{Agency Cost Theory}

Agency Cost Theory is of the opinion that managements of firms are agents of their shareholders. That, the shareholders expect the management to accommodate their interests. Costs, which emerge because of controlling activities of management, are called agency costs (Morri and Beretta, 2008). It illustrates that firm's capital structure is determined by agency cost, which includes the cost for both debt and equity issues. Agency costs exist due to the conflicts of interest between the owners of the firms and the managers. The costs which are related to equity issue may be included as the monitoring expenses for equity holders, and the bond expenses for the agent (Niu, 2008). Agency costs are costs to justify whether management acts consistently according to contractual agreement of firm with the shareholders [8].

\section{Traditional Theory}

The Traditional Theory of capital structure believes strongly on the relevance of optimal capital. According to the traditional theory, debt capital is cheaper than equity and as such a company can increase its value by borrowing up to a reasonable limit. The theory assumes that: (i) The cost of debt will remain constant until a significant point is reached when it would start to rise. (ii) The weighted average cost of capital (WACC) will fall immediately an external source of finance is introduced and will commence rising thereafter as the level of gearing increases. (iii) The company's market value and the market value per share will be maximized where WACC is at the lowest point. This theory opined that there is an optimal capital structure which maximizes the firm's value and minimizes the cost of capital; it is of the belief that the firm's value cannot be the same at different levels of capital structure.

\section{Review of Related Empirical Literature}

The literature on the impact of capital structure has produced mixed results. Some have found a positive relationship between financing choices and performance while some reported negative impact. For instances, Adeyemi and Oboh [9], examined the empirical effects of corporate capital structure on the market value of some selected firms listed on the Nigerian Stock Exchange. They used both descriptive and inferential statistics for their analysis. A sample size of 150 respondents and 90 firms were selected for both primary data and secondary data respectively. Descriptive statistics 
was used to analyze the primary data, while Chi-Square was used to draw inference of perceived relationship between capital structure and firm value. The results of the study suggested that a positively significant relationship existed between a firm's choice of capital structure and its market value in Nigeria. The study also suggested that listed firms in Nigerian capital market should strategically plan and manage their capital structure in order to maximize their market values. Strategically in the sense that they should use long term capital with a moderate short-term funds in their capital structure mix.

While, Ogebe; Ogebe, and Alewi [10], conducted a study on the impact of capital structure on firm performance in Nigeria from 2000 to 2010. They considered the impact of some key macroeconomic variables (gross domestic product and inflation) on firm performance. The traditional theory of capital structure was used to determine the significance of leverage and macroeconomic variables on firm's performance. The study made comparative analysis of the selected firms which were classified into highly and lowly geared firms setting a leverage threshold of above $10 \%$ as being highly geared. Using fixed effect regression estimation model, a relationship was established between performance (proxied by return on investment) and leverage of the firms over a period of ten years. Their result provided strong evidence in support of the traditional theory of capital structure which asserts that leverage is a significant determinant of firms' performance. A significant negative relationship was established between leverage and performance. From their findings, they strongly recommended that firms should use more of equity than debt in financing their business activities; their reason was that in spite of the fact that value of a business could be enhanced with debt capital, that it would get to a point that it would become unfavourable.

Chechet and Olayiwola [11], examined capital structure and profitability of the Nigerian listed firms from the Agency Cost Theory perspective with a sample of seventy (70) out of population of two hundred and forty-five firms listed on the Nigerian Stock Exchange (NSE) for the period of ten (10) years: 2000 - 2009. Panel data for the firms were generated and analyzed. Two independent variables which served as proxy for capital structure were used in the study: debt ratio and equity while profitability was used as the only dependent variable in the study. The result of the study showed that debt ratio was negatively related with profitability, while equity was directly related with profitability.

Leon (2013), studied the impact of capital structure on financial performance of the listed manufacturing firms in Sri Lanka from 2008 to 2012. Financial performance was measured in terms of accounting profitability by return on equity (ROE) and return on assets (ROA). 30 listed manufacturing firms were selected as sample. The data were analysed and hypotheses were tested through correlation and regression analysis by using
SPSS. The findings revealed that, there was a significant negative relationship between leverage and return on equity. And there was no significance relationship between leverage and return on assets.

Barine [12], examined capital structure determinants of quoted firms in Nigeria and lessons for corporate financing decisions. The results from the regression analysis of data obtained from seventeen financially successful quoted firms in Nigeria showed that capital structure was positively determined by cost of equity, existence of debt tax shield, covenant restrictions in debt agreements, firm dividend policy, competitor's capital mix and profitability; and was negatively determined by cost of debt, parent company influence and fear of financial distress necessitating new and financially unsuccessful firms to reduce debt/equity ratios when there existed a likelihood of increased financial distress and high cost of debt and increases it when cost of equity, profitability and benefits from tax shield is high, ensuring optimal trade-off between costs and net tax advantage of additional leverage, costs and benefits of equity in a firm's capital structure.

However, several scholars have revealed negative relationship between capital structure and performance in other lands. In this line, Kester (1986), found a negative relation between capital structure and performance (profitability) in the US and Japan. Similar results were reported by Friend and Lang (1988), Rajan and Zingales [13] in the G-7 countries. In addition, Huang and Song (2006), found a negative correlation between leverage and performance (earnings before interest and tax to total assets) in China firms.

Al-Taani [14], investigated the relationship between capital structure and firm performance across different industries using a sample of Jordanian manufacturing firms in Jordan. The annual financial statements of 45 manufacturing companies listed on the Amman Stock Exchange were used for the study which covered the period of five (5) years from 2005-2009. Multiple regression analysis was applied on performance indicators such as return on asset and profit margin as well as short-term debt to total assets, long term debt to total assets and total debt to equity as capital structure variables. The result showed a negative and insignificant relationship between short-term debt to total assets and longterm debt to total assets and return on assets and profit margin; while total debt to equity is positively related with return on assets and negatively related with profit margin. Short-term debt to total assets was significant using return on assets while long-term debt to total assets was significant using profit margin. The study concluded that, capital structure was not a major determinant of firm performance. The study therefore recommended that managers of manufacturing companies should exercise caution while choosing the amount of debt to use in their capital structure as it would likely affects their performance negatively, so to say. 
However, several studies over time, have showed either poor or no statistical relationship between capital structure and performance [15]. Ebaid [15] investigated the impact of capital structure choice on performance of 64 firms from 1997 to 2005 in the Egyptian capital market. He used three accounting -based measures; including return on assets (ROA), return on equity (ROE) and gross profit margin in his tests, and concluded that capital structure choices, generally, had a week-to-no impact on firm performance, generally.

From the foregoing discussions, the study has discovered that capital structure literatures and/or previous studies on capital structure had shown conflicting results among researchers. Some have shown that capital structure had significance impact on firm performance while others have shown no impact. Meanwhile, some researchers agreed that an association between capital structure and firm performance existed (Hung, 2002). However, some studies have concluded that the impact of capital structure on firm performance had both positive and negative [16-18] and inputs others therefore concluded that the impact was negative [19-22]. While, other studies have documented positive impacts [21-25]. For example, Chowdhury [24], examined the impact of capital structure on the value of shares of Bangladesh quoted firms. The study intended to provide a status on the extent to which a firm's capital structure might differ and how the value of firms changed. The study analyzed 77 companies from the four most dominant sectors of Bangladesh capital market. Cross sectional and time series fixed effect model was used to analyze its data to find out impact of capital structure on the firm value (expressed by the share price in the market). The model used put value of the firm (share price) as dependent variable; firm size, profitability, public ownership in capital structure, dividend payout, asset and operating efficiency, growth rate, liquidity and business risk were taken as independent variables. Firm size was represented by share capital, profitability was measured by earnings per share (EPS), public ownership was in percentage, capital structure was represented by the ratio of long term debt to total assets, dividend payout at actual, efficiency was measured by fixed asset turnover, growth rate was measured by sales growth rate, liquidity was measured by current ratio, and business risk was represented by operating leverage. All the variables used as independent variables were considered as proxies for the capital structure decisions of respective firms studied. The study established that there was a strong positive correlation between the firms' capital structure and value expressed by their share prices in the market.

\section{Research Methodology}

The data used in this study were secondary data sourced from the annual reports and financial statements of four (4) corporate firms in consumer goods sector listed on the Nigerian Stock Exchange, for the period between 2002 to 2016. The study used multiple regression of ordinary least square (OLS) method of analysis. The justification for the application of this analytical technique was based on the following premise highlighted by Gujarati and Porter [26]. They opined that the OLS regression is a linear function that gives a specific and precise result equivalent to the true value while other techniques tend to give generalized result which may limit the likely generated results [27].

\section{Model Specification}

In line with the objectives of this study, the model used by Onaolapo and Kajola [22], was adopted and modified to fit into the framework for the study in hand. The model shall be stated as follows:

$$
C S=f(L T D T A, T D T E C, S T D T A) \mathrm{Eq}(1)
$$

Equ 1 was modified in line with the objectives of the study that centred on Checht and Olayiwola [11]'s model as follows:

$$
\begin{aligned}
& C F P=f(\text { LTDTA,TDTEC }) \mathrm{Eq}(2) \\
& Y=\beta_{0}+\beta_{1} X_{1}+\beta_{2} X_{2}+\mu \mathrm{Eq}(3)
\end{aligned}
$$

Using the above multiple regression analysis model, the variables could be substituted with the following variables:

$C F P=\beta_{0}+\beta_{1} L T D T A+\beta_{2} T D T E C+\mu \mathrm{Eq}(4)$

Where:

CFP= Corporate Firm Performance (proxy for ROA)

ROA $=$ Returns on assets

LTDTA = Long term debts to total assets ratio

TDTEC $=$ Total debts to equity capital ratio

$\mathrm{CS}=$ Capital structure

$\beta_{0}=$ the constant

$\beta_{1}, \beta_{2}$, are regression coefficients or the parameters

$\mu=$ the Error term.

Note: Total short-term debts to total assets ratio was dropped in the present model because it is assumed that it increases costs of repayment of principal and being very costly it would negatively affect corporate returns).

\section{Hypotheses}

Ho

Long-term debt to total assets ratio has no significant impact on returns on assets of Nigerian firms. The above Table 1 indicated that the coefficient value was -0.032200 , the T-tabulated value was 1.76 while the probability value was 0.8059 and the critical value is -0.251163 all at more than $5 \%$ of significance level. Since the 
coefficient value was negative, the critical value was less than the T-tabulated value and the probability value is greater than 0.05 at $5 \%$ level of significance hence, the null hypothesis one is accepted, which implied that long-term debt to total asset ratio had negative and insignificant impact on corporate returns of assets of Nigerian firms studied (Table 2).

Table 1: Showing Ordinary Least Square Regression results.

\begin{tabular}{|c|c|c|c|c|}
\hline Variable & Coefficient & Std. Error & T-Statistic & Prob. \\
\hline $\mathrm{C}$ & 0.873124 & 0.186637 & 4.678189 & $0.0005^{*}$ \\
\hline LTDTA & -0.032200 & 0.128204 & -0.251163 & 0.8059 \\
\hline TDTEC & -0.040374 & 0.024404 & -1.654428 & $0.1239^{* *}$ \\
\hline R-squared & 0.198448 & $\begin{array}{l}\text { Mean } \\
\text { dependent } \\
\text { var }\end{array}$ & & \\
\hline $\begin{array}{l}\text { Adjusted } \\
\text { R-squared }\end{array}$ & 0.064856 & $\begin{array}{l}\text { S.D. } \\
\text { dependent } \\
\text { var }\end{array}$ & & 0.569603 \\
\hline $\begin{array}{l}\text { S.E. of } \\
\text { regression }\end{array}$ & 0.171667 & $\begin{array}{l}\text { Akaike info } \\
\text { criterion }\end{array}$ & & 0.177520 \\
\hline $\begin{array}{l}\text { Sum } \\
\text { squared } \\
\text { reside }\end{array}$ & 0.353635 & $\begin{array}{l}\text { Schwarz } \\
\text { criterion }\end{array}$ & & -0.509662 \\
\hline $\begin{array}{c}\text { Log } \\
\text { likelihood }\end{array}$ & 6.822466 & $\begin{array}{l}\text { Hannan- } \\
\text { Quinn } \\
\text { critter }\end{array}$ & & -0.368052 \\
\hline F-statistic & 1.485480 & $\begin{array}{c}\text { Durbin- } \\
\text { Watson stat }\end{array}$ & & -0.511171 \\
\hline $\begin{array}{c}\text { Prob(F- } \\
\text { statistic) }\end{array}$ & 0.265210 & & & 1.007229 \\
\hline
\end{tabular}

Source: E-view software package, 9.0.

Key: *significant at $1 \%$ level.

**significant at $10 \%$ level.

Table 2: Test of Hypothesis one.

\begin{tabular}{|c|c|c|c|}
\hline Variable & Coefficient & T-Statistic & Prob. \\
\hline LTDTA & -0.032200 & -0.251163 & 0.8059 \\
\hline T-tabulated $=1.76$ & & & \\
\hline
\end{tabular}

Source: Extracted from regression result Table 1.

\section{$\mathrm{Ho}_{2}$}

Total debts to equity capital ratio have no significant impact of returns on assets of corporate firms in Nigeria. The above Table 3 showed that the coefficient value was -0.040374 , the T-tabulated value was 1.76 while the probability (P-value) was 0.1239 and the critical value was -1.654428 all at more than $5 \%$ level of significance. Since the coefficient value was negative, and the critical value was less than the T-tabulated value while the probability value was greater than 0.05 at $5 \%$ level of significance, the null hypothesis two was also accepted. This implied that total debts to equity capital ratio had a negative and insignificant impact on returns of assets of corporate firms in Nigeria.
Table 3: Test of Hypothesis two.

\begin{tabular}{|c|c|c|c|}
\hline Variable & Coefficient & T-Statistic & Prob. \\
\hline TDTEC & -0.040374 & -1.654428 & $0.1239^{*}$ \\
\hline T-tabulated $=1.76$ & & & \\
\hline
\end{tabular}

Source: Extracted from regression result of Table 1.

Key: *significant at $10 \%$ level.

\section{Discussion of Findings}

The regression results showed that in hypothesis one that longterm debts to total assets ratio had a negative and insignificant impact on returns of assets of Nigerian firms, while in hypothesis two it was revealed that total debts to equity capital a ratio had negative and insignificant impact on returns on assets of corporate firms in Nigeria. Though it was tendering to significance at $10 \%$ level. It then means that increasing debt capital to equity capital in Nigeria would moderately influence corporate performance among Nigerian firms if it is prudently managed. Meanwhile, the $\mathrm{R}^{2}$ (co-efficient of determination) shows that the independent variables accounted for $19.84 \%$ of the changes in the dependent variable while the Prob(F-statistic) value of 0.265210 indicates that the overall model was statistically non-significant at $0.05 \%$ level of significance. While, Durbin-Watson stat. value of 1.007229 revealed that serial autocorrelation was not totally absent. So, since the Prob(F-statistic) value of the overall model is not significant, study therefore concluded that capital structure had no positive and significant impact on the performance of corporate firms in Nigeria based on result of this study. This finding is in line with the study conducted by Pratheepkanth [20] and Chechet and Olayiwola [11] which also reported that debt ratio was negatively related with performance, among Indian and Nigeria firms respectively so to speak.

\section{Conclusion}

The present study examined impact of capital structure on corporate performance in Nigeria with special focus on consumer goods firm sector of the economy. Based on the results from the study it was discovered that long-term debt, to total asset ratio had a negative and insignificant impact on returns on assets, while total debts to equity capital ratio also had a negative and insignificant impact on returns on assets although it was a tending to significance at 10 percent. The study, therefore, concluded that, capital structure represented by long- term debt to total assets (LTDTA) ratio and total debt to equity capital (TDTEC) ratio were not major determinants of a corporate firm's performance in Nigeria; hence, firms should finance their business activities with retained earnings and use corporate debt as a last option which is in line with the pecking order theory. The theory states that there is a hierarchy in choosing sources of financing. A firm will prefer to use internal financing than external financing. The internal 
financing is from the retained earnings that are earned by doing operational activities (Smart, 2004).

\section{Recommendations}

Based on thefindings of research the following recommendations are made to guide/policy in Nigeria:

a) That managers should be careful while using debts as a source of finance since a negative impact existed between the capital structure and corporate firm's performance in Nigerian investment climate. However, a prudent management of corporate debts has prospects of increasing returns in future.

b) That firms should try to finance their investment activities with retained earnings and use debt as a last option as this is consistent with the pecking order theory, which states that there is a hierarchy in choosing sources of financing. A firm will prefer to use internal financing than external financing. The internal financing is from the retained earnings that are earned by doing operational activities (Smart, 2004). This implies that, the study strongly recommends that corporate firms in Nigeria should use more of equity capital than debt capital in financing their business activities. This is because, notwithstanding of the fact that the value of a business could be enhanced with debt capital, it gets to a point that it becomes detrimental (negative) or unfavorable to the business performance. A well-managed corporate debt has the tendency to still increase corporate returns. Nigeria firms besides, should pursue policy of high proportion of retained earnings in their dividend policy decisions.

\section{Contribution to Knowledge}

This study has filled the following gaps; hence, it has contributed to knowledge:

a) This study has contributed to the literature by examining firm-specific factors that influenced the performance of Nigerian firms from the view point of their capital structure choices.

b) The present study has also helped us to understand Nigerian firms' capital structure choices and how it had affected their corporate performance.

c) The study has also contributed to methodological discourse in terms of techniques used in the presentation and analyses of the data for Nigerian firms.

\section{(Appendix 1 \& 2)}

\section{References}

1. Uremadu SO, Efobi RU (2012) The Impact of Capital Structure and Liquidity on Corporate Returns in Nigeria: Evidence from Manufacturing Firms. International Journal of Academic Research in Accounting, Finance and Management Sciences (2)3: 1-10.
2. Uremadu SO (2004) Financial Management: Concepts, Analysis and Applications, Enugu: Precision Publishers Limited.

3. Desai A (2007) Corporate Tax Avoidance and Firm Value. Journal of Harvard University and NBER 91(3): 537-546.

4. Modigilani F, Miller MH (1958) The Cost of Capital, Corporation Finance and the Theory of Investment. American Economic Review 3(48): 261297.

5. Al-Najjar B, Taylor P (2008) The Relationship between Capital Structure and Ownership Structure: Evidence from Jordanian Panel Data. Managerial Finance 34(12): 919-933.

6. Ross SA, Westerfield RW, Jaffe J (2005) Corporate Finance, Mc-Graw-Hill, New York, USA.

7. Nwude EC (2003) Basic Principles of Financial Management-A Second Course, Enugu: Chuke Nwabude Nigeria.

8. Jensen Z (2004) Notes on the Funding Structure of Non-Financial Firms from 1990-2003. South African Reserve Bank Quarterly, pp. 61-66.

9. Adeyemi SB, Oboh CS (2011) Perceived Relationship between Corporate Capital Structure and Firm Value in Nigeria. International Journal of Business and Social Science (2): 19.

10. Ogebe OP, Ogebe JO, Alewi K (2013) The Impact of Capital Structure on Firms' Performance in Nigeria.

11. Chechet IL, Olayiwola AB (2014) Capital Structure and Profitability of Nigerian Quoted Firms: The Agency Cost Theory Perspective. American International Journal of Social Science (3): 1.

12. Barine MN (2012) Capital Structure Determinants of Quoted Firms in Nigeria Lessons for Corporate Financing Decisions. Journal of Finance and Investment Analysis (1)2: 61-81.

13. Rajan RG, Zingales L (1995) What Do We Know About Capital Structure? Some Evidence from International Data. Journal of Finance (50)5: 14211460.

14. Al Taani K (2013) The Relationship between Capital Structure and Firm Performance: Evidence from Jordan. Journal of Finance and Accounting 1(3): 41-45.

15.Ebaid IE (2009) The Impact of Capital Structure Choice on Firm Performance: Empirical Evidence from Egypt. Journal of risk Finance (7): 477-487.

16. Tsangaao C, Kuei Chiu L, Yao Men Y (2009) Does Capital Structure Affect Operating Performances of Credit Cooperatives in Taiwan: Application of Panel Threshold Method. International Research Journal of Finance and Economics (32): 18-21.

17. Saeedi A and Mahmoodi I (2011) Capital Structure and Firm Performance: Evidence from Iranian Companies. International Research Journal and Economics (70): 20-26.

18. Oke 00, Afolabi B (2008) Capital Structure and Industrial Performance in Nigeria. Journal of Social Science 1(4): 13-21.

19. Narendar VR, Khamis HM, Lateef AS (2007) Capital Structure and Financial Performance: Evidence from Oman. Indian Journal of Economics and Business (2): 57-65.

20. Pratheepkanth P (2011) Capital Structure and Financial Performance: Evidence From Selected Business Companies in Colombo Stock Exchange, SriLanka. Journal of arts, Science and Commerce 2(2): 171173.

21. Shoaib A, Siddiqui MA (2011) Measuring Performance through Capital Structure: Evidence from Banking Sector of Pakistan. African Journal of Business Management 5(5): 1871-1878.

22. Onaolapo AA, Kajola SO (2010) Capital structure and firm performance: evidence from Nigeria. European Journal of Economics, Finance and Administrative Sciences (25): 70-77. 
23. Aman S (2011) Ownership structure and corporate performance: Evidence from India. International Journal of Humanities and Social Sciences 1(1): 23-29.

24. Chowdhury A, Chowdhuy PS (2010) Impact of capital structure on firm's value: Evidence from Bangladesh. Peer Reviewed and Open Access Journal (3)3: 111-115.

25. Omorogie AN, Erah DO (2010) Capital Structure and Corporate Performance in Nigeria: An Empirical Investigation. AAU Journal of Management Sciences 1(1): 43-52.
26. Gujarati DN, Porter DC (2009) Basic Econometrics. (5 $5^{\text {th }}$ edn.).McGrawHill Companies Inc, New York, USA.

27.Abor J (2005) The Effect of Capital Structure on Profitability: An Empirical Analysis of Listed Firms in Ghana. The Journal of Risk Finance (6): 5 .

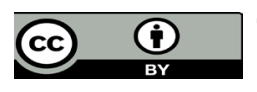

This work is licensed under Creative Commons Attribution 4.0 License

To Submit Your Article Click Here:

Submit Article

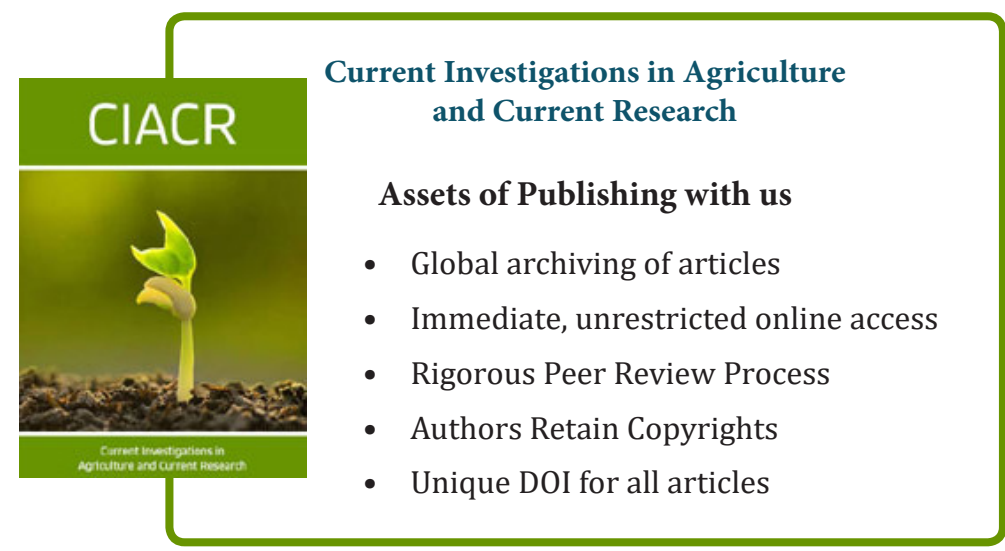

